\title{
The genus Hatschekia (Copepoda: Hatschekiidae) from pufferfishes (Tetraodontiformes: Tetraodontidae) off the Ryukyu Islands, Japan, with descriptions of four new species and a redescription of H. pholas
}

\author{
Daisuke Uyeno and Kazuya Nagasawa
}

Graduate School of Biosphere Science, Hiroshima University, 1-4-4 Kagamiyama, Higashi-Hiroshima, Japan

\begin{abstract}
Four new species of the genus Hatschekia Poche, 1902 (Copepoda: Siphonostomatoida: Hatschekiidae) are described based on female specimens collected from pufferfishes (Tetraodontiformes: Tetraodontidae) caught in coastal waters off the Ryukyu Islands, Japan: H. longiabdominalis sp. n. on Arothron hispidus (Linnaeus), H. geniculata sp. n. on A. hispidus (type host) and A. stellatus (Bloch et Schneider), H. ellipsocorpa sp. n. on A. mappa (Lesson), and H. boonah sp. n. on A. nigropunctatus (Bloch et Schneider) (type host) and A. meleagris (Schneider). Hatschekia longiabdominalis sp. n. and H. boonah sp. n. differ from all other congeners by sharing an unusual, projected abdomen and a fusiform trunk with posterior lobes; these two species are differentiated from each other by the shape of the dorsal chitinous frame on the cephalothorax. Hatschekia geniculata sp. n. can be distinguished by the combination of the following morphological characters: a rhomboidal cephalothorax with a pair of lateral conical protrusions, a cylindrical trunk with posterior lobes and a bent abdomen with a dorsal protrusion. Hatschekia ellipsocorpa sp. n. resembles H. pholas (Wilson, 1906) but can be distinguished from the latter by the possession of one distal and one inner setae on the terminal endopodal segment of legs 1 and 2. Hatschekia pholas is also redescribed based on female specimens from the tetraodontid A. stellatus. At present, 44 nominal species of the genus have been reported from Japan, including four new species described in this paper; 38 of them have been described originally from Japan.
\end{abstract}

Keywords: parasitic copepods, gill parasites, Arothron spp., taxonomy, identification key

The genus Hatschekia Poche, 1902 (Siphonostomatoida: Hatschekiidae) is one of the largest copepod groups parasitic on the gills of actinopterygian fishes (Boxshall and Halsey 2004). Identification of species of this genus is difficult because of their highly transformed trunk and vestigial appendages. The taxonomical study of the genus advanced significantly from the revision by Jones (1985). He clarified different confused taxonomic points in this genus and provided revised synonymies or homonyms for many species. He also highlighted the need to redescribe valid species, because their original descriptions were uninformative in several cases and type specimens were not available. Recently, Uyeno and Nagasawa (2009a) redescribed four species of the genus (H. iridescens Wilson, 1913, H. legouli Nunes-Ruivo, 1954, H. monacanthi Yamaguti, 1939 and H. ostracii Yamaguti, 1953) from Japan.

The family Tetraodontidae is a member of the actinopterygian order Tetraodontiformes and comprises nearly 130 species (Nelson 2006). Despite the high diversity of these teleost hosts, only one species, Hatschekia pholas (Wilson, 1906) from Sri Lanka and India, was known to parasitize fish of this family (Wilson 1906, Pillai 1968). In this paper, $H$. pholas is redescribed and four new species are described based on female specimens collected from tetraodontid fishes taken off the Ryukyu Islands, Japan.

\section{MATERIALS AND METHODS}

A total of seven specimens of marine tetraodontid fishes were collected by spear fishing or purchased at fishing ports from May 2005 to May 2009 in six localities off the Ryukyu Islands, Japan. Copepods attached to the hosts' gills were carefully removed and preserved in $80 \%$ ethanol. A specimen of Arothron meleagris (Schneider) was also examined at the Faculty of Science, University of the Ryukyus (URM). Copepod specimens were soaked in lactophenol for 10 to 12 hours before dissection. The appendages of the copepods were dissected and observed using the method of Humes and Gooding (1964). The drawings were made with the aid of a drawing tube at $100 \times$ to $1500 \times$ magnifications. The morphological terminology follows Huys and Boxshall (1991). Specimens were measured according to the method proposed by Uyeno and Nagasawa (2009a). Measurements in micrometres are shown as ranges with means and standard deviations in parentheses. The variation in the setation 
pattern of the terminal segments of exopods and endopods are shown as mode and ranges in parentheses. The ratios of length of various body parts and appendages are shown in Table 1. Type specimens of the new species and voucher specimens of H. pholas were deposited at the National Museum of Nature and Science, Tsukuba (NSMT) and the University of the Ryukyus Museum, Fujukan (RUMF), Okinawa. Type specimens and a voucher specimen were loaned from the National Museum of Natural History (USMN), Smithonian Institution, Washington, D.C. The scientific names of fishes follow those listed by Hayashi (2002) and Froese and Pauly (2012).

\section{RESULTS}

Order Siphonostomatoida Thorell, 1859

Hatschekiidae Kabata, 1979

Hatschekia Poche, 1902

\section{Hatschekia pholas (Wilson, 1906)}

Figs. 1, 2

\section{Syn.: Caetrodes pholas Wilson, 1906}

Female (based on ten newly collected specimens):

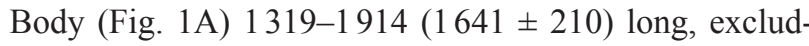
ing caudal rami. Cephalothorax ellipsoidal, shorter than wide, $733-865(811 \pm 41) \times 815-1000(876 \pm 57)$, greatly protruded backward over trunk, bearing dorsal Y-shaped chitinous frame. Trunk fusiform with narrow neck region, longer than wide, 942-1434 (1 196 \pm 153$) \times 420-788$ $(592 \pm 114)$, greatest width at midlength, bearing knoblike projection on lateral margin anterior to leg 3 and posterior processes. Urosome (Fig. 1B) shorter than wide, $125-202(158 \pm 25) \times 164-239(195 \pm 24)$. Caudal ramus (Fig. 1B) longer than wide, 93-126 $(110 \pm 11) \times 49-64$ $(57 \pm 5)$, carrying five naked setae. All specimens armed with apron-like chitinous lamella attached to the anterior border of urosome.

Rostrum with long, rod-like process on each posterolateral corner (Fig. 1C). Antennule (Fig. 1C) indistinctly five-segmented, 380-490 (437 \pm 40$)$ long; setal formula per segment: 9, 5, 4, 1, $13+1$ aesthetasc. Proximal segment bearing an additional, vestigial seta. Antenna (Fig. 1D) three-segmented, proximal segment (coxa) unarmed, middle segment (basis) ornamented with surface pits, terminal claw without armature. Segment size: proximal segment 102-156 (131 \pm 15$)$, middle 279-347 (314 \pm 22$)$, claw length 47-71 (59 \pm 7$)$; total length 470 549 (502 \pm 26). Parabasal papilla (Fig. 1D) round. Oral cone robust. Mandible (Fig. 1E) slender, with five sharp subapical teeth. Maxillule (Fig. 1F) bilobed; lobes armed each with two tapering elements. Maxilla (Fig. 1G) foursegmented; proximal segment unarmed, second segment rod-like, with one basal seta, third segment elongate, with one distal seta. Terminal segment small, with one short seta and bifid claw. Maxilliped absent.

Legs 1 and 2 (Fig. 2A, B) biramous, with exopods represented by two incompletely fused segments and twosegmented endopods; leg armature formula as follows:

\begin{tabular}{lccc}
\hline & Protopod & Exopod & Endopod \\
\hline Leg 1 & $1-1$ & $1-0 ; 5(4-5)$ & $0-0 ; 3$ \\
Leg 2 & $1-0$ & $1-0 ; 4(4-5)$ & $0-0 ; 3(2-3)$ \\
\hline
\end{tabular}

Distal segments of rami on legs 1 and 2, excluding endopod of leg 1 , showing variability in the setation pattern shown as mode and ranges in parentheses.

Leg 1 (Fig. 2A) 193-267 (229 \pm 24) long; protopod 93-123 (108 \pm 11$)$, exopod 92-144 (120 \pm 15$)$, exceeding endopod length 59-98 (72 \pm 13$)$. Leg 2 (Fig. 2B) long 215-307 (254 \pm 31$)$; protopod 110-152 (126 \pm 14$)$, exopod 100-160 (128 \pm 18$)$, endopod 80-138 (103 \pm 17$)$. Endopods of legs 1 and 2 with setae on distal tips only (Fig. 2C, D), intercoxal sclerite of legs 1 and 2 naked (Fig. 2E, F). Protopods and rami of legs 1 and 2 ornamented with rows of blunt, fine spinules on anterior surface.

Leg 3 (Fig. 2G) represented by two simple setae on mid-lateral surface of trunk with basement slightly swollen. Leg 4 (Fig. $2 \mathrm{H}$ ) represented by single lateral seta on posterior three fourth of trunk.

Syntype females (based on two specimens; USMN 56658): possess all characters of other specimens, except antennule and legs 1 and 2. These appendages damaged and insufficient to count armature formula. Measurements of body parts as follows: body length 857-895, cephalothorax length 616-674, cephalothorax width 654-727, trunk length 524-533, trunk width 427, urosome length 79-108, urosome width 137-149, caudal ramus length 67-73, caudal ramus width 43-51. Antenna length 385-396, length of proximal segment of antenna $87-101$, length of middle segment of antenna 247-252, length of terminal claw of antenna 46-49. Leg 1 174187 long; protopod 70, exopod 74-104, endopod 43-58. Leg 2 length 201-215; protopod 68-96, exopod 84-106, and endopod 63-80.

Type host: Arothron stellatus (Bloch et Schneider) (Tetraodontiformes: Tetraodontidae).

Type locality: Pearl Banks, Indian Ocean, Sri Lanka (GPS data absent). Collected 1 July 1902 (USMN 56658); unknown date in 1906 (USMN 74297).

Other localities: Off Henza-jima Island $\left(26^{\circ} 21^{\prime} \mathrm{N}\right.$, $\left.127^{\circ} 59^{\prime} \mathrm{E}\right)$, Kin Bay, Ryukyu Islands, North Pacific Ocean, Japan. Collected 23 July 2007 (NSMT-Cr 20920); off Toya $\left(26^{\circ} 21^{\prime} \mathrm{N}, 147^{\circ} 42^{\prime} \mathrm{E}\right)$, Okinawa-jima Island, Ryukyu Islands, East China Sea, Japan. Collected 9 May 2009 (NSMT-Cr 20921).

Site of infection: Gill filaments.

Deposition of specimens: One female (USMN 74297); six females (NSMT-Cr 20920); three females (NSMT-Cr 20921).

Type specimens examined: Two syntype females (USMN 56658).

Remarks. This species was originally described by Wilson (1906) as Caetrodes pholas based on a female specimens from Arothron stellatus (as Tetraodon stella- 
A

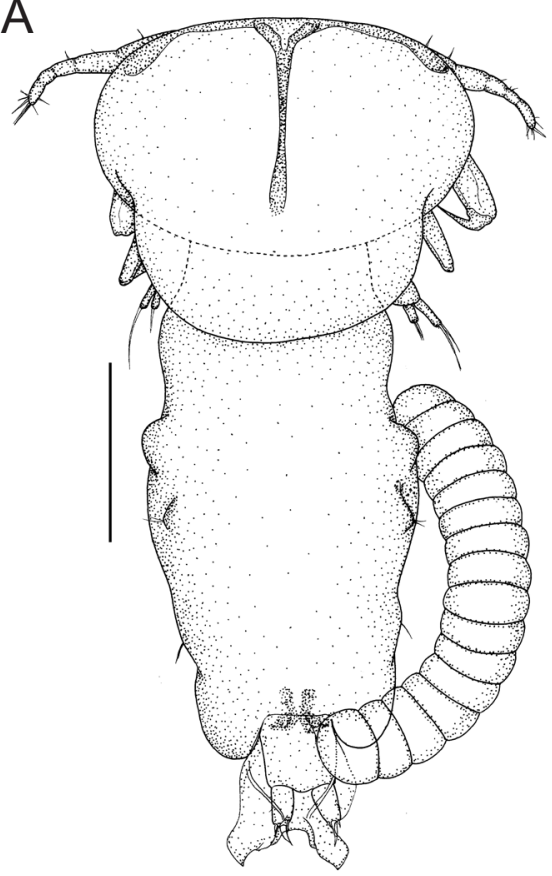

B

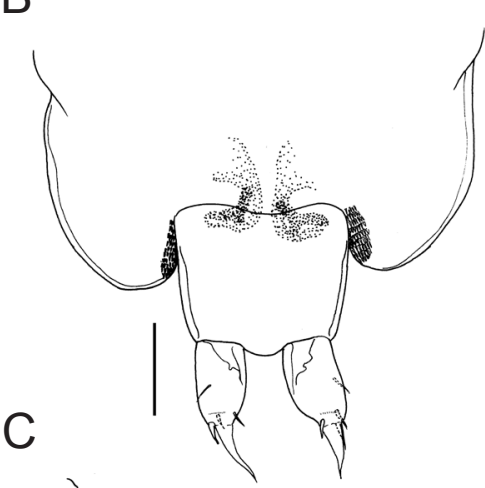

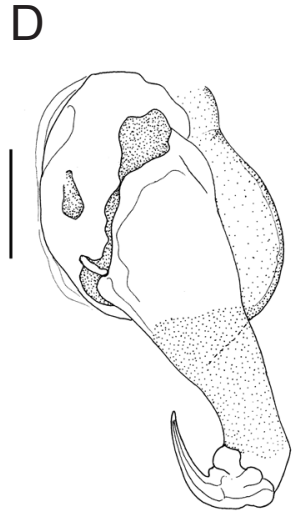

E $\quad F$
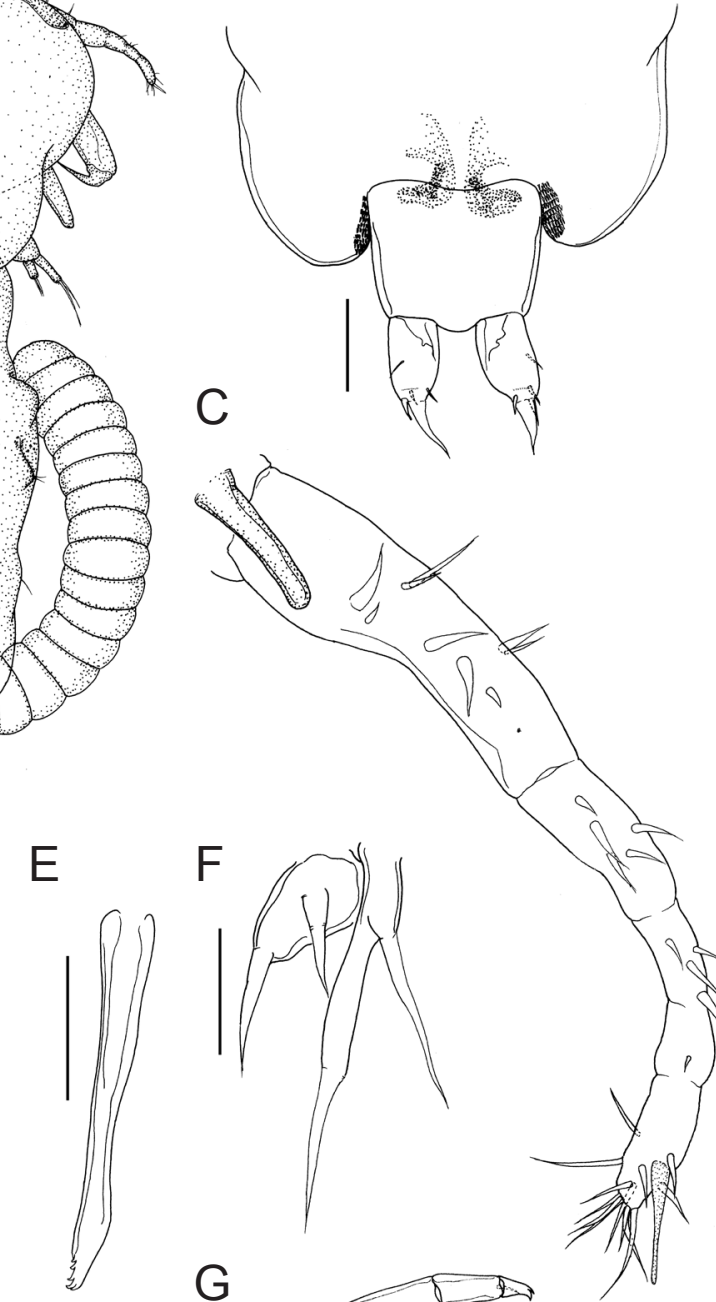

$\mathrm{F}$
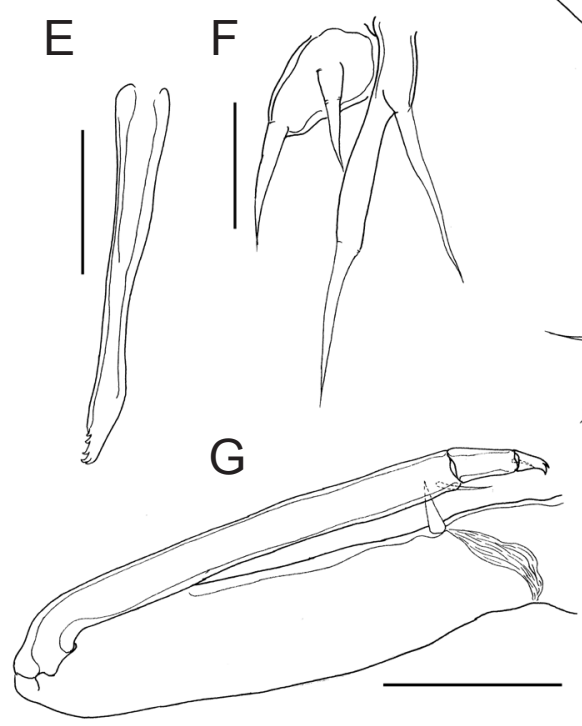

Fig. 1. Hatschekia pholas, female, NSMT-Cr 20920. A - habitus, dorsal; B - posterior part of trunk, dorsal; C - antennule, ventral; $\mathbf{D}$ - antenna and parabasal papilla, ventral; $\mathbf{E}$ - mandible; $\mathbf{F}$ - maxillule; $\mathbf{G}$ - maxilla. Scale-bars: A $=400 \mu \mathrm{m} ; \mathrm{B}-\mathrm{D}=100 \mu \mathrm{m}$; $\mathrm{E}, \mathrm{F}=40 \mu \mathrm{m} ; \mathrm{G}=80 \mu \mathrm{m}$.

tus) caught from off Sri Lanka (as Ceylon). It was subsequently redescribed using female specimens from Tetraodon cutcutia Hamilton (as Monotretus cutcutia) captured in Trivandrum, India and transferred to Hatschekia (Pillai 1967, 1968). However, the record of T. cutcutia as a host is doubtful and may have been caused by contamination because this host species is potamodromous, being usually found in rivers (Froese and Pauly 2012). No species of Hatchekia has been recorded from fresh to brackish waters. In this study, we found this species on $A$. stellatus caught in offshore waters of the sea.

This species is characterized by the cephalothorax having a well developed, projecting posterior margin. This rare character is also shared with $H$. seyi Ho et Kim, 2001. However, $H$. seyi differs from this species in having six setae on the caudal ramus and in the lack of posterior lobes on the trunk.

There are several discrepancies between our observations and the descriptions made by previous authors. For instance, the trunk in our specimens possesses lateral protrusions but Wilson (1906) and Pillai (1968) did not describe or illustrate such protrusions. These protrusions are not easily spotted under the microscope because of the thickness of the trunk in this species; these structures may have been overlooked. The protrusions were found in both syntypes (USMN 56658) observed in this study. 


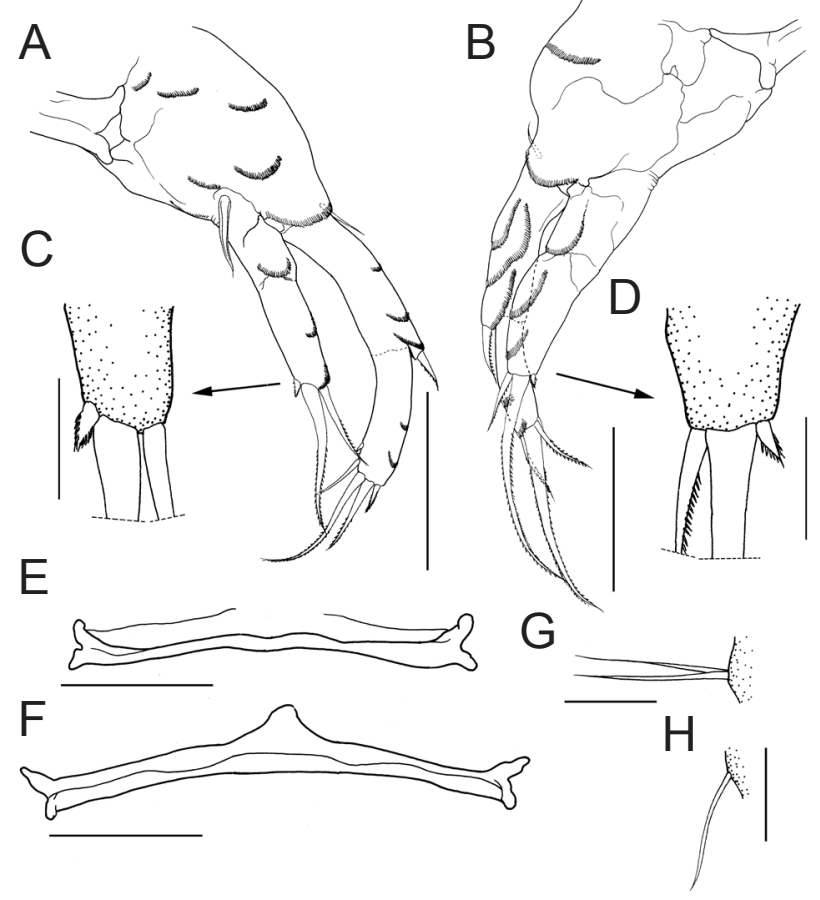

Fig. 2. Hatschekia pholas, female, NSMT-Cr 20920. A - leg 1, anterior view; B - leg 2, anterior view; $\mathbf{C}$ - distal tip of leg 1 endopod; D - distal tip of leg 2 endopod; $\mathbf{E}$ - intercoxal sclerite of leg 1, anterior view; $\mathbf{F}$ - intercoxal sclerite of leg 2, anterior view; $\mathbf{G}-\operatorname{leg} 3 ; \mathbf{H}-\operatorname{leg} 4$. Scale-bars: A, B $=80 \mu \mathrm{m}$; $\mathrm{C}, \mathrm{D}=20 \mu \mathrm{m} ; \mathrm{E}, \mathrm{F}=40 \mu \mathrm{m} ; \mathrm{G}, \mathrm{H}=30 \mu \mathrm{m}$.

Wilson (1906, fig. 50) found $14(1,1,1,3,0,8)$ setae on five segments of the anntenule, whereas Pillai (1968, fig.16) described $29(6,4,4,1,14)$, and the other specimens have $33(9,5,4,1,13+1$ aesthetasc) elements. Both Wilson (1906) and Pillai (1968) did not illustrate any fine, smaller antennular setae and probably overlooked some of the smallest elements. The antennules of the syntypes were damaged and thus the authors were unable to count the accurate number of elements.

Wilson (1906, figs. 54, 55) found that the exopods of legs 1 and 2 were distinctly segmented and Pillai (1968) made a similar observation. The exopods of these legs in our observation, however, are incompletely two-segmented. This discrepancy in segmentation may be due to inadequate observations. In addition, both authors did not describe nor illustrate the presence of rows of blunt spinules on the protopods, rami of legs 1 and 2. However, the syntypes and other specimens we observed are ornamented with rows of blunt spinules. Pillai (1968) found fine denticles on both the rami of leg 1 and the exopod of leg 2, which may be his interpretation of the blunt spinules we found.

Villalba (1986) collected two specimens of Hatschekia sp. from Arothron meleagris (Schneider) off Easter Island, Chile and suggested that they might be identical with $H$. pholas. However, the specimens distinctly differ from $H$. pholas by having the cephalothorax with a sinu- ous lateral margin, which is not shared with $H$. pholas (see Wilson 1906, Pillai 1968; present study).

Our finding of $\mathrm{H}$. pholas represents the first record of the species from Japan and the North Pacific Ocean.

'Indo-eranomi' is proposed as a new Japanese name of H. pholas.

Hatschekia longiabdominalis sp. $\mathrm{n}$.

Figs. 3, 4

Female (based on nine specimens): Body (Fig. 3A) 951-1 132 (1 $055 \pm 65)$ long, excluding caudal rami. Cephalothorax ellipsoid, frontal margin concave in middle, shorter than wide 198-256 $(223 \pm 18) \times 319-414$ $(363 \pm 26)$, with dorsal, M-shaped chitinous frame, four pits bearing one setule each and two setules on chitinous frame (Fig. 3B). Trunk longer than wide, 791-945 $(866 \pm 56) \times 236-282(250 \pm 14)$, fusiform, posterior to basis of leg 2, widest at base of leg 3 as anterior one third, with wrinkled posterior lobe. Urosome (Fig. 3C) extending backward beyond posterior lobes of trunk, slightly longer than wide 86-123 $(103 \pm 12) \times 80-110(95 \pm 9)$, pinched in middle and posterior two thirds. Caudal ramus (Fig. 3C) fused to urosome, longer than wide, 31-45 $(37 \pm 5) \times 21-29(25 \pm 2)$, bearing five naked setae.

Rostrum with short, rounded thumb-like process at each posterolateral corner (Fig. 3D). Antennule (Fig. 3D) indistinctly five-segmented, 193-231 (212 \pm 12$)$ long; armature formula: 10, 5, 4, 1, $13+1$ aesthetasc. Antenna (Fig. 3E) three-segmented, proximal segment (coxa) unarmed, middle segment (basis) ornamented with surface pits. Terminal claw ornamented with surface pits, bearing one basal process. Proximal segment length 30-60 $(46 \pm 8)$, middle segment length $105-135(122 \pm 11)$, terminal claw length 26-37 (32 \pm 4$)$; total length 170-229 (199 \pm 17). Parabasal papilla (Fig. 3F) well developed, hump-form. Oral cone general shape, robust, composed of labrum, mandible, and labium. Mandible (Fig. 3G) slender, with four sharp subapical teeth. Maxillule (Fig. 3H) bilobed, lobes armed with two tapering elements. Maxilla (Fig. 3I) four-segmented; proximal segment unarmed; second segment rod-like, with one basal seta; third segment elongate, with one distal seta. Terminal segment small, with one short seta and bifid claw. Maxilliped absent.

Legs 1 and 2 (Fig. 4A, B) biramous, with exopods represented by two incompletely fused segments and twosegmented endopods; leg armature formula as follows:

\begin{tabular}{lccc}
\hline & Protopod & Exopod & Endopod \\
\hline Leg 1 & $1-1$ & $1-0 ; 5(4-6)$ & $0-0 ; 3(2-4)$ \\
Leg 2 & $1-0$ & $1-0 ; 4(4-5)$ & $0-0 ; 3(2-3)$ \\
\hline
\end{tabular}

Distal segments of rami on legs 1 and 2 show variability in setation pattern shown as mode and ranges in parentheses.

Some setae plumose. Leg 1 (Fig. 4A) 106-117 (112 \pm 4$)$ long; protopod length 54-60 $(57 \pm 2)$, exopod 51-60 
A

B
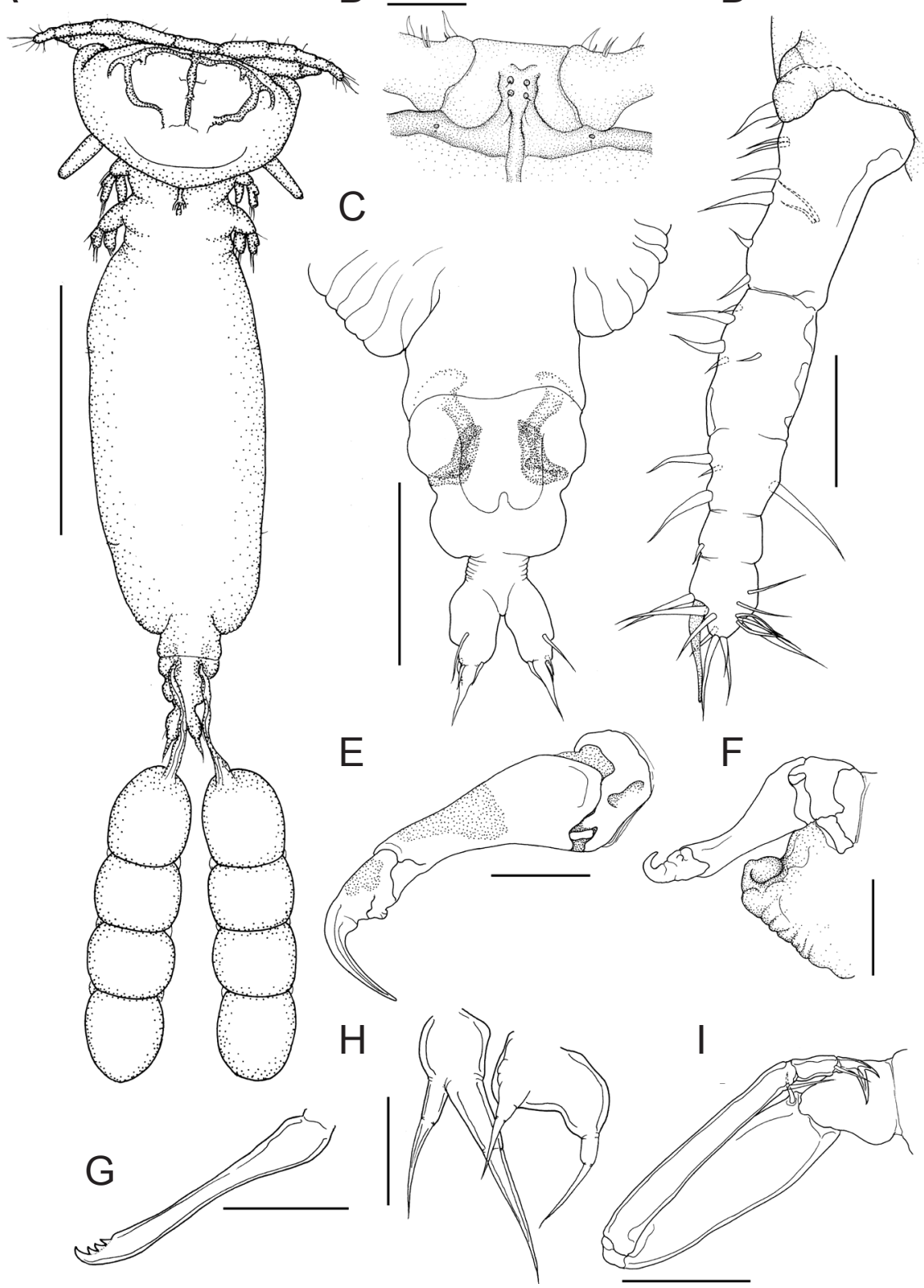

Fig. 3. Hatschekia longiabdominalis sp. n., female, holotype NSMT-Cr 20922. A - habitus, dorsal; B - anterior surface of cephalothorax, dorsal; $\mathbf{C}$ - posterior part of trunk, dorsal; $\mathbf{D}$ - antennule, ventral; $\mathbf{E}$ - antenna, ventral; $\mathbf{F}$ - antenna with parabasal papilla; $\mathbf{G}$ - mandible; $\mathbf{H}$ - maxillule; I-maxilla. Scale-bars: A $=400 \mu \mathrm{m} ; \mathrm{B}, \mathrm{D}, \mathrm{E}, \mathrm{I}=50 \mu \mathrm{m} ; \mathrm{C}=100 \mu \mathrm{m} ; \mathrm{F}=30 \mu \mathrm{m} ; \mathrm{G}, \mathrm{H}=20 \mu \mathrm{m}$.

$(55 \pm 3)$ exceeding endopod length $36-46(41 \pm 3)$. Leg 2 (Fig. 4B) 119-144 (127 \pm 7$)$; protopod 67-77 (72 \pm 3$)$; exopod 50-71 (55 \pm 6$)$, endopod 55-61 (59 \pm 2$)$. Intercoxal sclerite of legs 1 and 2 (Fig. 4C, D) with rod-like projection halfway of anterior margin. Intercoxal sclerite of leg 1 bearing four rounded processes, with wrinkled tips. Intercoxal sclerite of leg 2 bearing similar processes but somewhat smaller and less well developed than in first leg. Protopods and rami of legs 1 and 2 ornamented with rows of blunt, fine spinules on anterior surface.

Leg 3 (Fig. 4E) represented by two simple setae on anterior one third of trunk with slightly swollen base. Leg 4
(Fig. 4F) represented by simple lateral seta on posterior two third of trunk.

Type host: Arothron hispidus (L.) (Tetraodontiformes: Tetraodontidae).

Type locality: Off Henza-jima Island $\left(26^{\circ} 21^{\prime} \mathrm{N}\right.$, $\left.127^{\circ} 59^{\prime} \mathrm{E}\right)$, Kin Bay, Ryukyu Islands, North Pacific Ocean, Japan. Collected 23 July 2007 (NSMT-Cr 20922).

Other locality: Off Zamami-jima Island $\left(26^{\circ} 13^{\prime} \mathrm{N}\right.$, $\left.127^{\circ} 17^{\prime} \mathrm{E}\right)$, Ryukyu Islands, East China Sea, Japan. Collected 23 May 2005 (NSMT-Cr 20923; RUMF-ZC00932).

Site of infection: Gill filaments. 


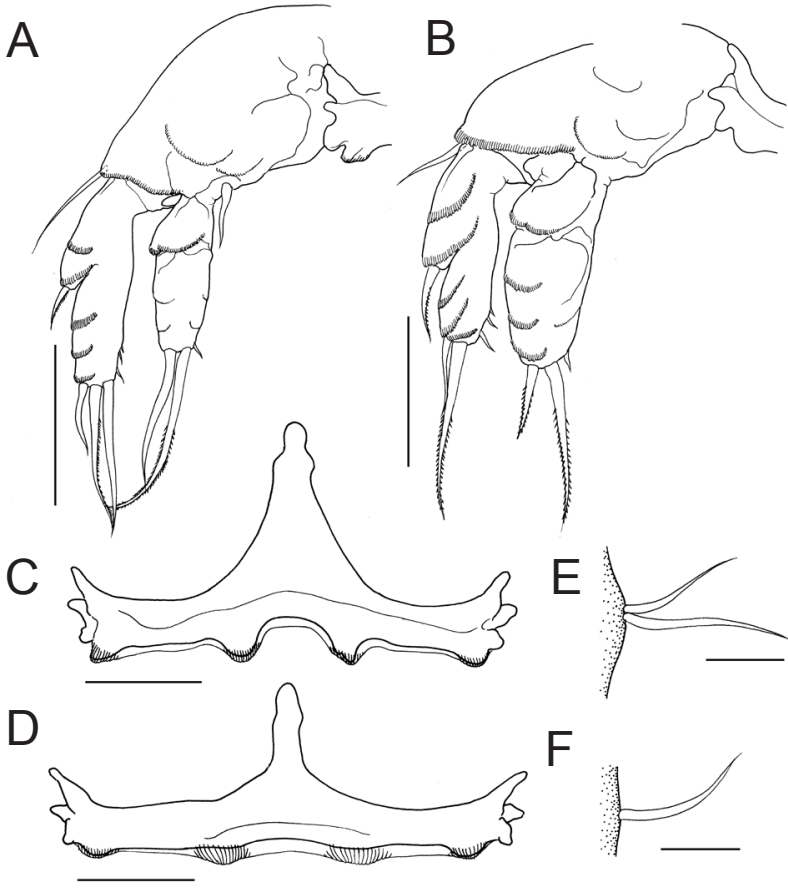

Fig. 4. Hatschekia longiabdominalis sp. n., female, holotype NSMT-Cr 20922. A - leg 1, anterior view; B - leg 2, anterior view; $\mathbf{C}$ - intercoxal sclerite of leg 1, anterior view; $\mathbf{D}$ - intercoxal sclerite of leg 2, anterior view; $\mathbf{E}-\operatorname{leg} 3$, ventral; $\mathbf{F}-\operatorname{leg} 4$, ventral. Scale-bars: A, B $=40 \mu \mathrm{m} ; \mathrm{C}, \mathrm{D}=30 \mu \mathrm{m} ; \mathrm{E}, \mathrm{F}=10 \mu \mathrm{m}$.

Deposition of specimens: Holotype female (NSMTCr 20922); four paratype females (NSMT-Cr 20923); four paratype females (RUMF-ZC-00932).

E t y m o log y: The specific name of this new species, longiabdominalis, refers to its long, posteriorly projected urosome.

Remarks. Hatschekia longiabdominalis sp. $\mathrm{n}$. is easily distinguishable from all other congeners by having a fusiform trunk with posterior lobes and the urosome markedly projecting beyond posterior lobes of the trunk. This species is also separated from all other congeners by having unique intercoxal sclerites of legs 1 and 2, which strongly project from the middle of the anterior margin and bear four blunt processes on the posterior margin.

'Sazanamifugu-no-eranomi' is proposed as a new Japanese name of $H$. longiabdominalis sp. $\mathrm{n}$.

\section{Hatschekia geniculata sp. n.}

Figs. 5, 6

Female (based on nine specimens): Body (Fig. 5A) 1804-2213 (2056 \pm 145$)$ long, excluding caudal rami. Cephalothorax rhomboid, slightly shorter than wide 313-379 (343 \pm 27$) \times 390-525(466 \pm 46)$, with dorsal M-shaped chitinous frame; lateral margin blunt, forming lateral protrusion; frontal margin weakly projected, flanked by antennules. Trunk cylindrical with constriction posterior to leg 2, longer than wide 1509-1874 $(1722 \pm 126) \times 383-571(464 \pm 83)$, widest at anterior one third, with rod-like anterior chitinous rib and posteri- or lobes. Abdomen (Fig. 5B, C) shorter than wide, 83-142 $(96 \pm 18) \times 92-120(110 \pm 10)$, bent ventrally, bearing dorsal protrusion. Caudal ramus (Fig. 5B) slightly longer than wide, $31-43(38 \pm 4) \times 18-26(22 \pm 3)$, armed with five naked setae.

Rostrum with short digitiform process on each posterolateral margin (Fig. 5D). Antennule (Fig. 5D) indistinctly five-segmented, 294-393 (325 \pm 25$)$ long; armature formula: 10, 5, 4, 1, $13+1$ aesthetasc. Antenna (Fig. 5E) three-segmented; proximal segment (coxa) unarmed, middle segment (basis) ornamented with surface pits, terminal claw with single basal seta. Proximal segment length 49-67 (61 \pm 6$)$, middle segment length 113-184 $(150 \pm 19)$, terminal length $34-54(41 \pm 6)$; total length 215-298 (252 \pm 22$)$. Parabasal papilla (Fig. 5F) well developed, consisting of rod-like process and knob-like process. Oral cone robust. Mandible (Fig. 5G) slender, with four sharp apical teeth. Maxillule (Fig. 5H) bilobed; lobes armed each with two subequal tapering elements. Maxilla (Fig. 5I) four-segmented; proximal segment unarmed; second segment rod-like, with single basal seta; third segment elongate, with single distal seta; terminal segment small, with small seta and bifid claw. Maxilliped absent.

Legs 1 and 2 (Fig. 6A, B) biramous, exopods represented by two incompletely fused segments and twosegmented endopods; both rami bearing blunt setae. Leg armature formula as follows:

\begin{tabular}{lccc}
\hline & Protopod & Exopod & Endopod \\
\hline Leg 1 & $1-1$ & $1-0 ; 6(4-6)$ & $0-0 ; 3$ \\
Leg 2 & $1-0$ & $1-0 ; 5(3-5)$ & $0-0 ; 3(2-3)$ \\
\hline
\end{tabular}

Distal segments of rami on legs 1 and 2, excluding endopod of leg 1 , show variability in setation pattern shown as mode and ranges in parentheses.

Leg 1 (Fig. 6A) 140-198 (179 \pm 17) long; protopod 74-95 (87 \pm 7 ), exopod 67-104 (92 \pm 12$)$, endopod 37-69 $(57 \pm 10)$. Leg 2 (Fig. 6B) length 163-215 (201 \pm 16$)$; protopod 95-118 $(106 \pm 7)$, exopod 67-116 $(95 \pm 13)$, endopod 71-100 (89 \pm 9$)$. Intercoxal sclerite of legs 1 and 2 (Fig. 6C, D) without armature. Protopods and rami of legs 1 and 2 ornamented with rows of blunt, fine spinules on anterior surface.

Leg 3 (Fig. 6E) represented by two simple setae on anterior third of trunk. Leg 4 (Fig. 6F) represented by simple lateral seta on posterior two thirds of trunk.

Type host: Arothron hispidus (Tetraodontiformes: Tetraodontidae).

Other host: Arothron stellatus (Tetraodontiformes: Tetraodontidae).

Type locality: Off Red Beach $\left(26^{\circ} 26^{\prime} \mathrm{N}, 127^{\circ} 54^{\prime} \mathrm{E}\right)$, Kin Bay, Okinawa-jima Island, Ryukyu Islands, North Pacific Ocean, Japan. Collected 29 March 2005 (NSMT-Cr 20924). Other localities: Off Zamami-jima Island $\left(26^{\circ} 13^{\prime} \mathrm{N}\right.$, 


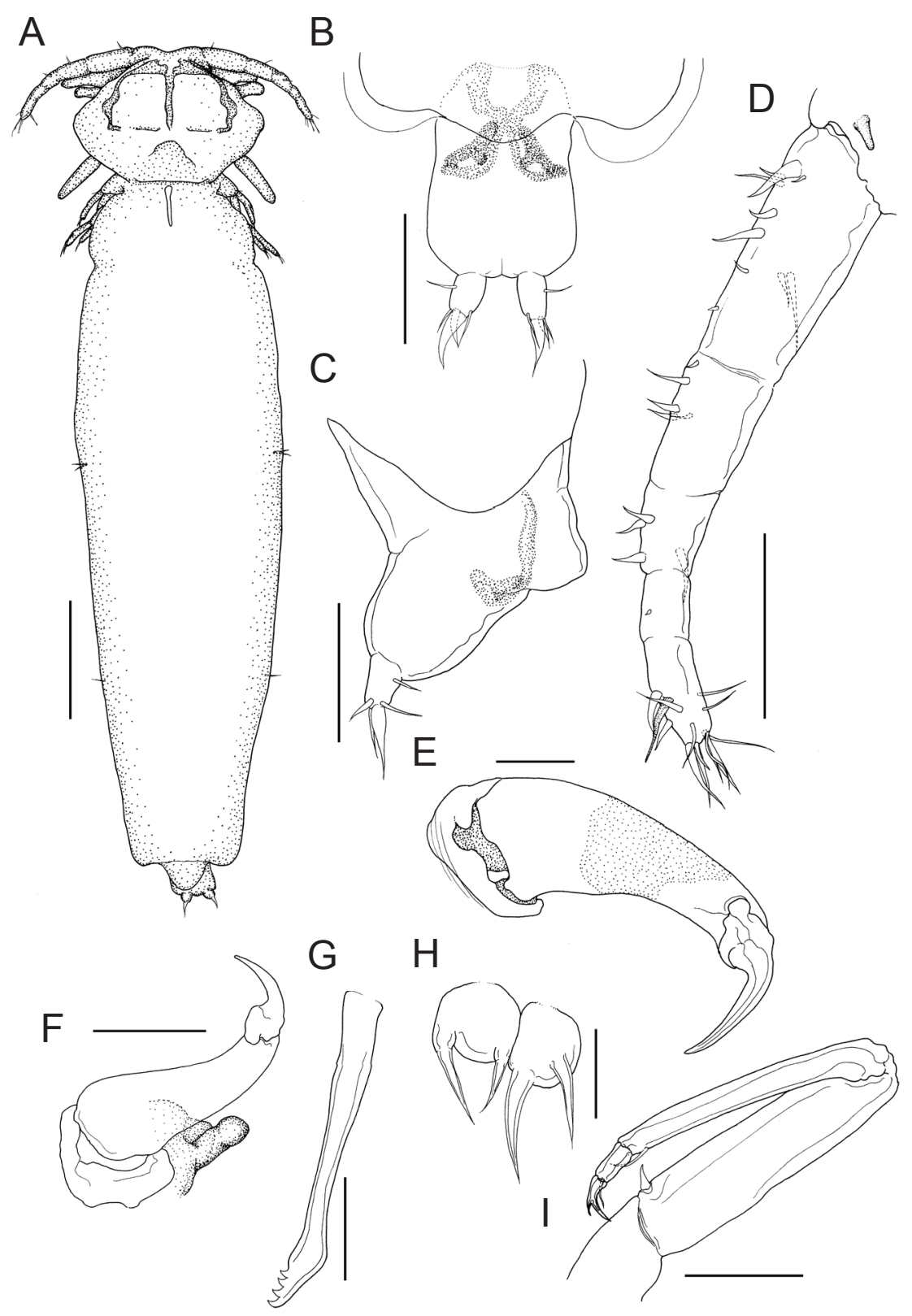

Fig. 5. Hatschekia geniculata sp. n., female, holotype NSMT-Cr 20924. A - habitus, dorsal; B - posterior part of trunk, dorsal; $\mathbf{C}$ - posterior part of trunk, lateral; D - antennule, ventral; $\mathbf{E}$ - antenna, ventral; $\mathbf{F}$ - antenna with parabasal papilla; $\mathbf{G}$ - mandible; H - maxillule; I - maxilla. Scale-bars: A $=300 \mu \mathrm{m} ; \mathrm{B}-\mathrm{D}, \mathrm{F}=100 \mu \mathrm{m} ; \mathrm{E}=50 \mu \mathrm{m} ; \mathrm{G}=40 \mu \mathrm{m} ; \mathrm{H}=30 \mu \mathrm{m} ; \mathrm{I}=60 \mu \mathrm{m}$.

$\left.127^{\circ} 17^{\prime} \mathrm{E}\right)$, Ryukyu Islands, East China Sea, Japan. Collected 23 May 2005 (NSMT-Cr 20925); off Henza-jima Island $\left(26^{\circ} 21^{\prime} \mathrm{N}, 127^{\circ} 59^{\prime} \mathrm{E}\right)$, Kin Bay, Ryukyu Islands, North Pacific Ocean, Japan. Collected 23 July 2007 (NSMT-Cr 20926); off Toya $\left(26^{\circ} 21^{\prime} \mathrm{N}, 147^{\circ} 42^{\prime} \mathrm{E}\right)$, Okinawa-jima Island, Ryukyu Islands, East China Sea, Japan. Collected 9 May 2009 (RUMF-ZC-00933).

Site of infection: Gill filaments.

Deposition of specimens: Holotype female (NSMTCr 20924); three paratype females (NSMT-Cr 20925 from A. hispidus); two paratype females (NSMT-Cr 20926 from A. hispidus); three females (RUMF-ZC-00933 from A. stellatus).
E ty mology: The specific name of the new species refers to its bent urosome.

Remarks. Hatschekia geniculata sp. n. resembles H. girelli Jones et Cabral, 1990, H. labracis (van Beneden, 1871) and H. longigenitalis Yamaguti, 1954 by having a rhomboid cephalothorax with a pair of lateral hemispherical protrusions. The new species is easily differentiated by its trunk having an anterior constriction posterior to leg 2, posterior lobes and a bent abdomen with a dorsal protrusion.

'Koppepan-eranomi' is proposed as a new Japanese name of $H$. geniculata sp. n. 


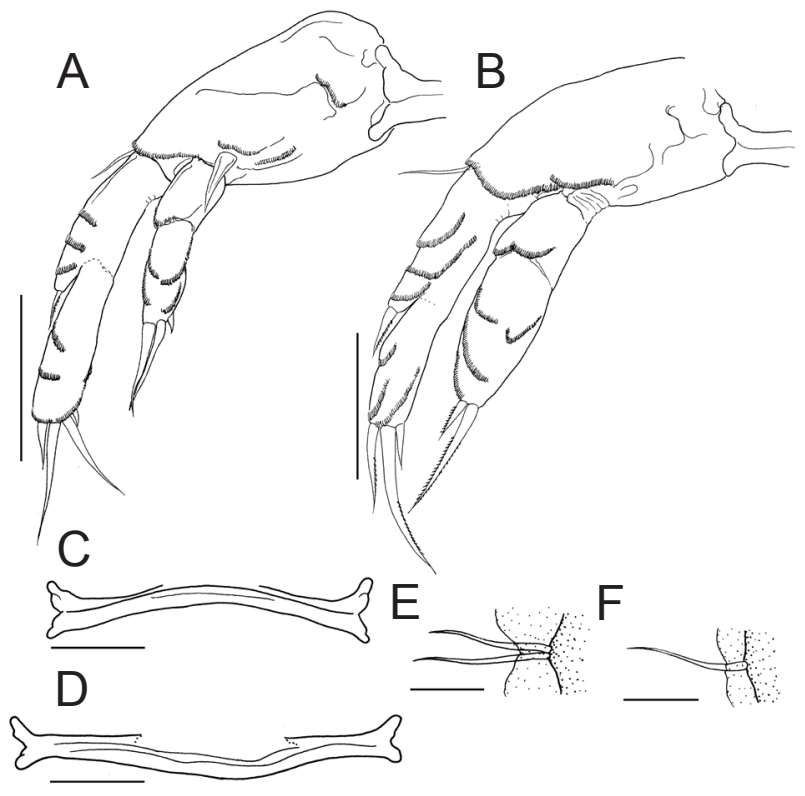

Fig. 6. Hatschekia geniculata sp. n., female, holotype NSMTCr 20924. A - leg 1, anterior view; B - leg 2, anterior view; $\mathbf{C}$ - intercoxal sclerite of leg 1, anterior view; D - intercoxal sclerite of leg 2, anterior view; $\mathbf{E}-\operatorname{leg} 3 ; \mathbf{F}-\operatorname{leg} 4$. Scale-bars: $\mathrm{A}, \mathrm{B}=60 \mu \mathrm{m} ; \mathrm{C}, \mathrm{D}=50 \mu \mathrm{m} ; \mathrm{E}, \mathrm{F}=10 \mu \mathrm{m}$.

\section{Hatschekia ellipsocorpa sp. n.}

Figs. 7, 8

Female (based on nine specimens): Body (Fig. 7A, B) 648-1 $086(860 \pm 130)$ long, excluding caudal rami. Cephalothorax rounded rhomboid, slightly shorter than wide $260-356(313 \pm 33) \times 437-588(496 \pm 57)$, frontal and posterior margins rounded, lateral margin expanding at midlength, distinctly wider than trunk, with dorsal, chitinous Y-shaped frame (Fig. 7C). Trunk ovate or ellipsoid, with weak constriction at base of leg 2 518-767 $(617 \pm 77) \times 285-436(351 \pm 55)$, with posterior lobes, trunk widest at base of leg 2 and tapering posteriorly. Urosome (Fig. 7D) shorter than wide, 25-67 (41 \pm 16$) \times 55$ $91(74 \pm 8)$. Caudal ramus (Fig. 7D) longer than wide, $28-39(36 \pm 3) \times 15-23(18 \pm 2)$, armed with five naked setae.

Rostrum with short, thumb-like digitiform process on each posterolateral corner. Antennule (Fig. 7E) indistinctly five-segmented, 206-292 (244 \pm 32) long. Armature formula: 10, 5, 4, 1, $13+1$ aesthetasc. Antenna (Fig. 7F) three-segmented; proximal segment (coxa) unarmed, middle segment (basis) ornamented with surface pits. Terminal claw without armature. Proximal segment length 58-95 (69 \pm 12$)$, middle segment length 137-181 $(162 \pm 15)$, terminal segment length $29-43(35 \pm 4)$; total length 241-304 (265 \pm 21$)$. Parabasal papilla (Fig. 7F) well developed, round. Oral cone robust. Mandible (Fig. 7G) slender, with four sharp and one small apical teeth. Maxillule (Fig. 7H) bilobed; lobes armed each with two tapering elements. Maxilla (Fig. 7I) four-segmented.
Proximal segment unarmed, second segment rod-like, with single basal seta; third segment elongate, with one distal seta. Terminal segment small, with bifid claw. Maxilliped absent.

Legs 1 and 2 (Fig. 8A, B) biramous, with exopods represented by two incompletely fused segments and twosegmented endopods; some setae on both rami blunt. Leg armature formula as follows:

\begin{tabular}{lccc}
\hline & Protopod & Exopod & Endopod \\
\hline Leg 1 & $1-1$ & $1-0 ; 4(4-5)$ & $0-0 ; 2$ \\
Leg 2 & $1-0$ & $1-0 ; 3(3-5)$ & $0-0 ; 2$ \\
\hline
\end{tabular}

Distal segments of exopod on legs 1 and 2 show variability in setation pattern shown as mode and ranges in parentheses.

Leg 1 (Fig. 8A) 99-141 (124 \pm 16) long; protopod 50-74 (63 \pm 9$)$, exopod 49-71 (61 \pm 8$)$, endopod 40-56 $(47 \pm 6)$. Leg 2 (Fig. 8B) length 120-172 (146 \pm 19 ); protopod 64-90 (76 \pm 10$)$, exopod 55-81 $(70 \pm 10)$, endopod 54-77 $(65 \pm 9)$. Endopods of legs 1 and 2 with one distal and one inner setae (Fig. 8C, D). Intercoxal sclerites of legs 1 and 2 (Figs. 8E, F) naked, but holotype and some specimens with thin, membraneous structure on posterior margin. Protopods and rami of legs 1 and 2 ornamented with rows of blunt, fine spinules on anterior surface.

Leg 3 (Fig. 8G) represented by two simple setae on mid-lateral line of trunk surface. Leg 4 (Fig. 8H) represented by simple lateral seta on posterior three fourths of trunk.

Type host: Arothron mappa (Lesson) (Tetraodontiformes: Tetraodontidae).

Type locality: Off Red Beach $\left(26^{\circ} 26^{\prime} \mathrm{N}, 127^{\circ} 54^{\prime} \mathrm{E}\right)$, Kin Bay, Okinawa-jima Island, Ryukyu Islands, North Pacific Ocean, Japan. Collected 5 April 2009 (NSMT-Cr 20927, 20928) and 12 January 2009 (RUMF-ZC-00934).

Site of infection: Gill filaments.

Deposition of specimens: Holotype female (NSMTCr 20927); five paratype females (NSMT-Cr 20928); three paratype females (RUMF-ZC-00934).

E ty mology: The specific name of the new species, ellipsocorpa, refers to its ellipsoidal trunk.

Remarks. Hatschekia ellipsocorpa sp. n. is distinguishable from its congeners by following characters: an oval or ellipsoidal trunk with posterior lobes; the endopods of legs 1 and 2 lacking setae on inner distal margin on the proximal segment and bearing one distal and one inner seta on the terminal segment; an expanded, transversely rhomboidal cephalothorax with round, smooth margin; intercoxal sclerites of legs 1 and 2 unarmed or with membraneous structures on posterior margins. The new species has an oval or ellipsoidal trunk with posterior lobes. This type of trunk is shared with 18 species of the genus $[H$. breviramus Lewis, 1967; H. delamarei Nuñes-Ruivo, 1954; H. elliptica Pillai, 1967; H. exigua 


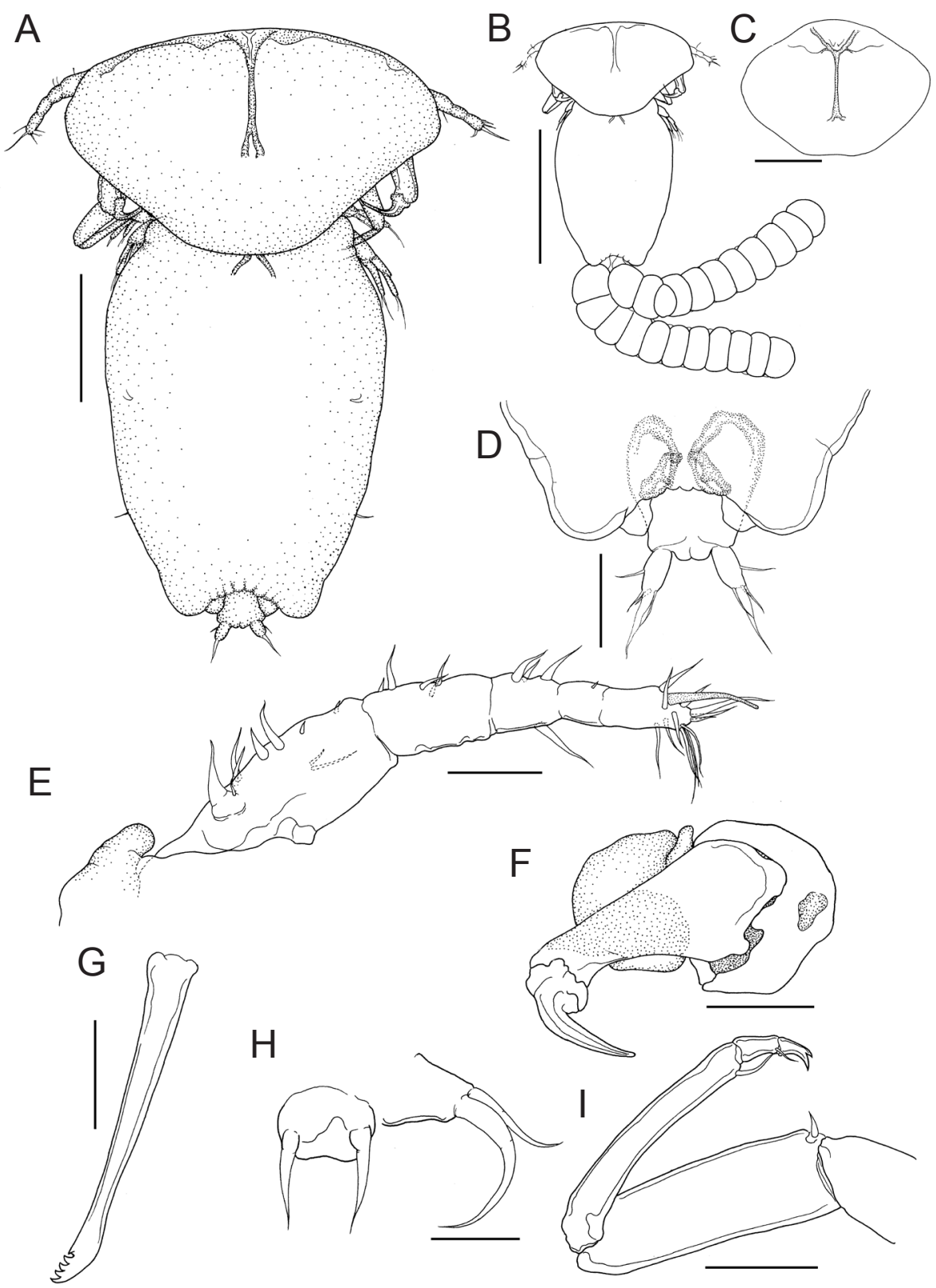

Fig. 7. Hatschekia ellipsocorpa sp. n., female, holotype NSMT-Cr 20927. A - habitus, dorsal; B - habitus dorsal with egg sacs; C - cephalothorax, anterodorsal; D - posterior part of trunk, dorsal; $\mathbf{E}$ - antennule, ventral; $\mathbf{F}$ - antenna with parabasal papilla; $\mathbf{G}$ - mandible; H - maxillule; I- maxilla. Scale-bars: A, C = $200 \mu \mathrm{m} ; \mathrm{B}=500 \mu \mathrm{m} ; \mathrm{D}=80 \mu \mathrm{m} ; \mathrm{E}, \mathrm{I}=50 \mu \mathrm{m} ; \mathrm{F}=70 \mu \mathrm{m} ; \mathrm{G}, \mathrm{H}=20 \mu \mathrm{m}$.

Pearse, 1951; H. gerro Leigh-Sharpe, 1936; H. insolita Wilson, 1913; H. iridescens Wilson 1913; H. ischnon Leigh-Sharpe, 1936; H. legouili Nuñes-Ruivo, 1954; H. napoleoni Jones et Cabral, 1990; H. ostracii Yamaguti, 1953; H. petiti Nuñes-Ruivo, 1954; H. pholas (Wilson, 1906); H. pinguis Wilson, 1908; H. pontini Nuñes-Ruivo, 1954; H. pygmaea Scott et Scott, 1913; H. sumireyakko Uyeno et Nagasawa, 2012; H. uncata Wilson, 1913]. Nine species $(H$. delamarei, H. exigua, H. gerro, $H$. insolita, $H$. iridescens, H. legouili, H. napoleoni, $H$. petiti, $H$. sumireyakko) differ from the new species in having the endopod with more than three setae on the distal tip of legs 1 and 2 and one inner seta on the proximal segment of leg 2 (vs. legs 1 and 2 bearing endopods with two setae and a seta absent on the proximal segment of leg 2 in H. ellipsocorpa sp. n.). The new species is distynguished from $H$. breviramus, $H$. ostracii, $H$. pinguis and $H$. uncata in having an expanded, transversely rhomboidal cephalothorax with round, smooth margin (vs. the cephalothorax with notches on anterior margin, suborbicular, oval with lateral margin slightly indented, or bearing postero-lateral margin abruptly indented, respectively). Hatschekia ostracii also differs from the new species in having the intercoxal sclerite of legs 1 and 2 with four processes on 


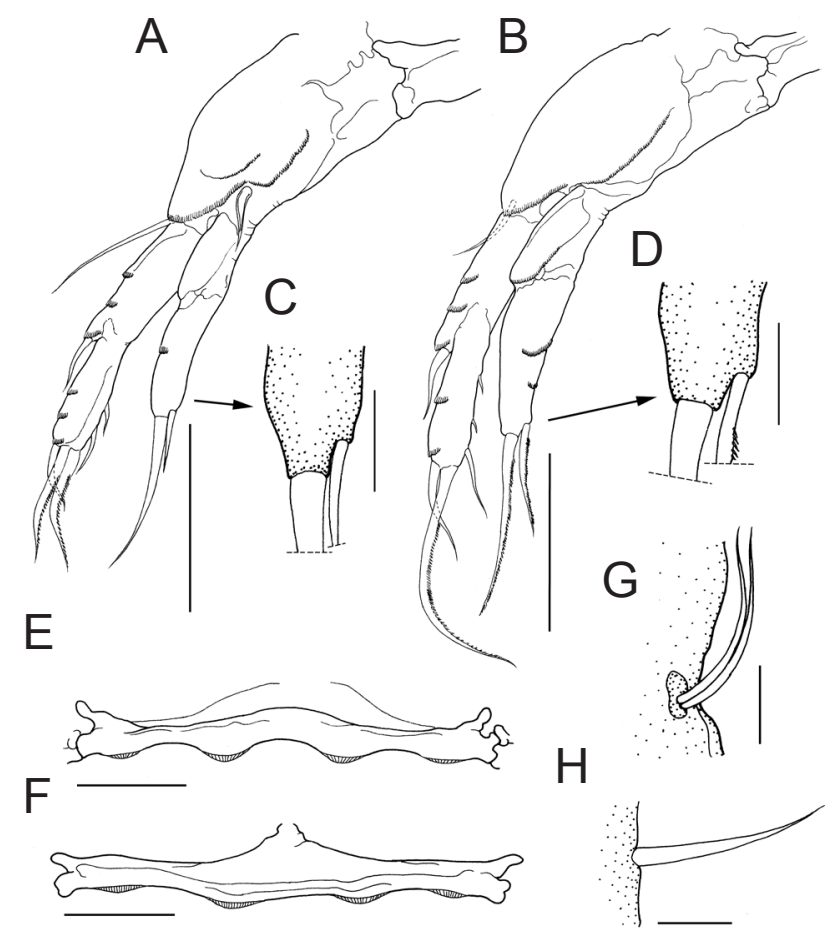

Fig. 8. Hatschekia ellipsocorpa sp. n., female, holotype NSMTCr 20927. A - leg 1, anterior view; B - leg 2, anterior view; $\mathbf{C}$ - tip of leg 1 endopod; D - tip of leg 2 endopod; $\mathbf{E}$ - intercoxal sclerite of leg 1, anterior view; $\mathbf{F}$ - intercoxal sclerite of leg 2, anterior view. $\mathbf{G}-\operatorname{leg} 3 ; \mathbf{H}-\operatorname{leg} 4$. Scale-bars: $\mathrm{A}, \mathrm{B}, \mathrm{E}, \mathrm{F}=50 \mu \mathrm{m} ; \mathrm{C}, \mathrm{D}, \mathrm{G}, \mathrm{H}=10 \mu \mathrm{m}$.

the posterior margin (vs. the intercoxal sclerites of legs 1 and 2 unarmed or with membraneous structures on posterior margins in the new species). Hatschekia elliptica is ditinguished from the new species by its segmented urosome and by having six setae on the caudal ramus. Hatschekia ischnon differs from the new species in having the oval cephalothorax with a visible keel on its dorsal surface and the endopod of legs 1 and 2 with four distal setae (vs. the rhomboid cephalothorax bearing Y-shaped dorsal frame and the endopods of legs 1 and 2 with two setae in the new species). The cephalothorax length/body length and cephalothorax width/cephalothorax length ratios in H. ischnon, 0.21 (Jones 1985) vs. $0.37 \pm 0.05$ and 0.84 (Jones 1985) vs. $1.59 \pm 0.11$ (Table 1), are smaller than those in the new species.Hatschekia pontini has four to seven setae on the terminal endopodal segment of legs 1 and 2 (Yamaguti 1939, Nuñes-Ruivo 1954) (vs. the endopods of legs 1 and 2 bearing two setae on terminal segment). Hatschekia pygmaea is separated from the new species by bearing the antennule with one distal spine on the posterior margin of the proximal segment (vs. the antennule lacks spine). Hatschekia pholas differs from the new species by having a posteriorly protruded cephalothorax covering the anterior part of the trunk, although there are intraspecific variations in the cephalothorax morphology (Pillai 1968; present data). The new species also differs from $H$. pholas in having the endopods of legs 1 and 2 with one distal seta and one inner seta (Fig. 8C, D) (vs. the endopods of legs 1 and 2 bearing three and two to three distal setae, respectively). From our observations and those by Pillai (1968), the endopods of legs 1 and 2 of $H$. pholas have two or three distal setae and lack an inner seta.

The new species somewhat resembles Hatschekia sp. as described by Villalba (1986), based on a single specimen recovered from Arothron meleagris in Chile. However, this species can be discriminated from the new species in having its cephalothorax with a wavy lateral margin and three constrictions in the anterior quarter, mid-lateral and posterior three fourths of the trunk (Villalba 1986, fig. 1).

'Keshoufugu-no-eranomi' is proposed as a new Japanese name of H. ellipsocorpa sp. $\mathrm{n}$.

\section{Hatschekia boonah sp. $\mathrm{n}$.}

Figs. 9, 10

Female (based on twelve specimens): Body (Fig. 9A) 831-1031 (929 \pm 58$)$ long, excluding caudal rami. Cephalothorax rounded triangular, frontal margin nearly straight, lateral margin expanding transversely at anterior quarter, shorter than wide, 291-359 (327 \pm 22$) \times 400-463$ (426 \pm 18$)$, with dorsal, Y-shaped chitinous frame. Trunk fusiform pinched at posterior three fourth, longer than wide, 586-773 $(673 \pm 48) \times 267-334(311 \pm 21)$, bearing anterior bifid chitinous frame on dorsal surface, with posterior round lobes. Urosome (Fig. 9B) protruding, extending markedly beyond posterior lobes of trunk, shorter than wide, 50-74 $(62 \pm 7) \times 89-101(94 \pm 4)$, with lateral knob-like protrusion, posterior corner extending. Caudal ramus (Fig. 9B) longer than wide, 25-34 $(29 \pm 3) \times 14$ $26(16 \pm 2)$ and bearing five naked setae.

Rostrum with rod-like process on each posterolateral corner (Fig. 9C). Holotype bearing this process of right side with one filament-like apical structure. Antennule (Fig. 9C) indistinctly five-segmented, 190-247 $(220 \pm 18)$ long; armature formula: 10, 5, 4, 1, $13+1$ aesthetasc. Antenna (Fig. 9D) three-segmented, proximal segment (coxa) unarmed, middle segment (basis) ornamented with surface pits, terminal claw with one basal small, papilliform process, proximal segment length 67$86(76 \pm 7)$, middle segment length $169-206(187 \pm 11)$, terminal segment length 29-39 (34 \pm 3$)$; total length 276317 (297 \pm 13). Parabasal papilla (Fig. 9E) developed with wrinkled surface, composed of round tip and small papilliform tip. Oral cone robust. Mandible (Fig. 9F) slender, with four sharp subapical teeth. Maxillule (Fig. 9G) bilobed; each lobe armed with two tapering elements. Maxilla (Fig. 9H) four-segmented; proximal segment unarmed; second segment rod-like, with one basal seta; third segment elongate, with one distal seta; terminal segment small, with bifid claw (it is uncertain whether small seta present or not). Maxilliped absent. 


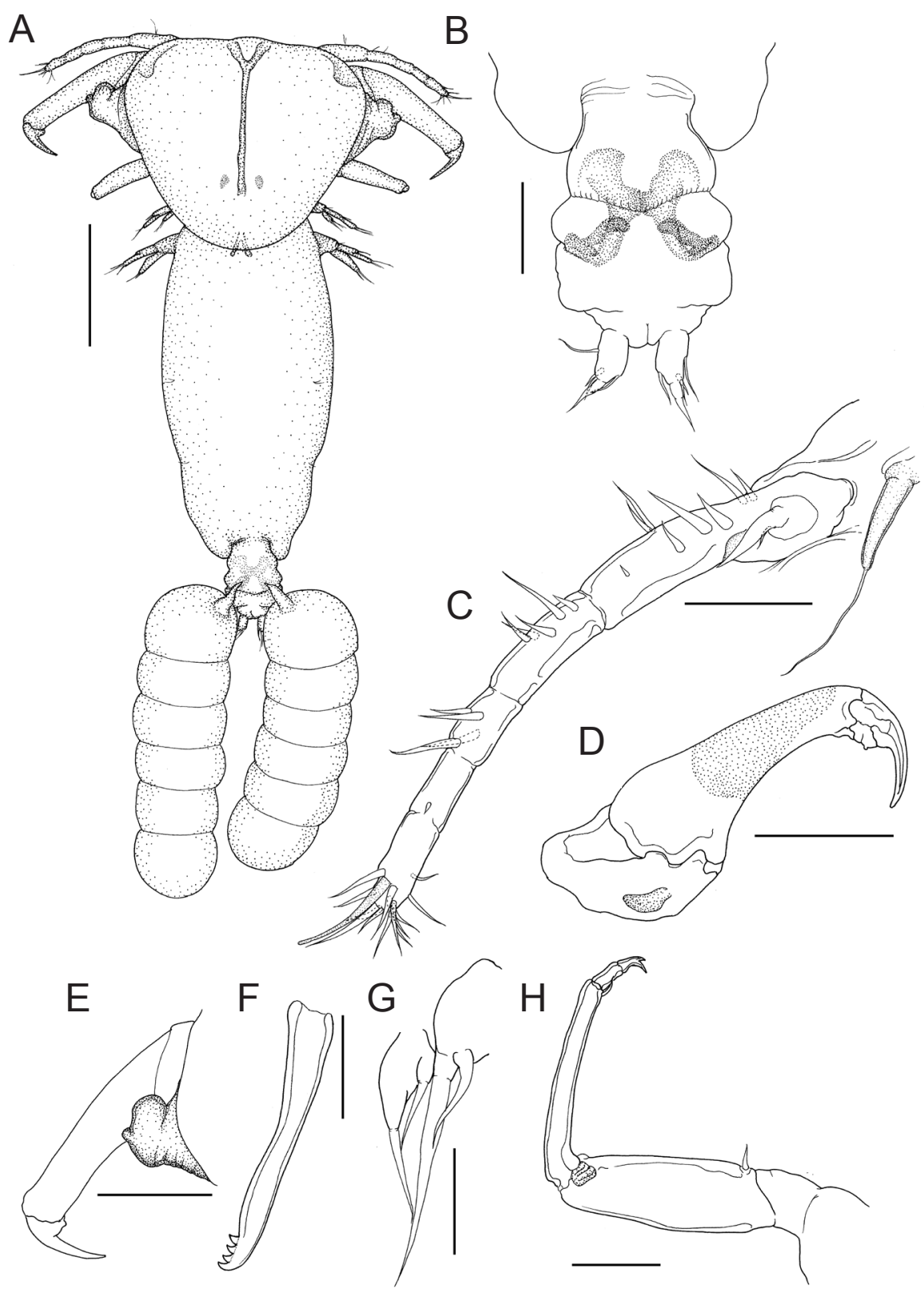

Fig. 9. Hatschekia boonah sp. n., female, holotype NSMT-Cr 20929. A - habitus, dorsal; B - posterior part of trunk, dorsal; C - antennule, ventral; D - antenna, ventral; $\mathbf{E}$ - antenna with parabasal papilla; $\mathbf{F}$ - mandible; $\mathbf{G}$ - maxillule; $\mathbf{H}$ - maxilla. Scale-bars: $\mathrm{A}=200 \mu \mathrm{m} ; \mathrm{B}, \mathrm{C}, \mathrm{H}=50 \mu \mathrm{m} ; \mathrm{D}, \mathrm{E}=100 \mu \mathrm{m} ; \mathrm{F}, \mathrm{G}=20 \mu \mathrm{m}$.

Legs 1 and 2 (Fig. 10A, B) biramous, with exopods composed of two incompletely fused segments and twosegmented endpods; leg armature formula as follows:

\begin{tabular}{lccc}
\hline & Protopod & Exopod & Endopod \\
\hline Leg 1 & $1-1$ & $1-0 ; 4$ & $0-0 ; 2(2-3)$ \\
Leg 2 & $1-0$ & $1-0 ; 4$ & $0-0 ; 2$ \\
\hline
\end{tabular}

Distal segment of endopod on leg 1 shows variability in setation pattern shown as mode and ranges in parentheses.

Protopod, exopod and endopod of legs 1 and 2 with semicircular rows of flat, blunt spinules. Legs 1 and 2 bearing some spines on inner margin on endopod and rami, respectively. Leg 1 (Fig. 10A) 101-131 (115 \pm 8$)$ long; protopod 49-66 (57 \pm 4$)$, exopod 52-66 (57 \pm 4$)$, endopod 31-41 (34 \pm 3 ). Leg 2 (Fig. 10B) length 115141 (129 \pm 9$)$; protopod 56-76 (66 \pm 6$)$, exopod 57-67 (63 \pm 4$)$, endopod 46-64 $(56 \pm 5)$. Intercoxal sclerite of legs 1 and 2 (Fig. 10C, D) without armature.

Leg 3 (Fig. 10E) represented by two simple setae on mid-lateral surface of trunk. Leg 4 (Fig. 10F) represented by simple lateral seta on posterior three fourth of trunk.

Type host: Arothron nigropunctatus (Schneider) (Tetraodontiformes: Tetraodontidae). 


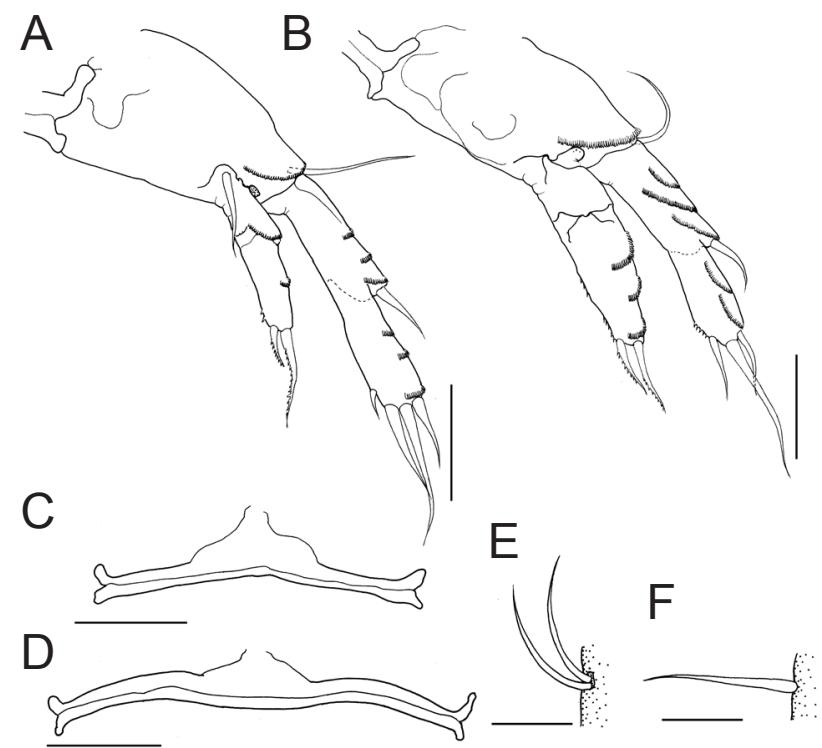

Fig. 10. Hatschekia boonah sp. n., female, holotype NSMTCr 20929. A - leg 1, anterior view; B - leg 2, anterior view; $\mathbf{C}$ - intercoxal sclerite of leg 1, anterior view; $\mathbf{D}$ - intercoxal sclerite of leg 2, anterior view; $\mathbf{E}-\operatorname{leg} 3 ; \mathbf{F}-\operatorname{leg} 4$. Scale-bars: $\mathrm{A}, \mathrm{B}=30 \mu \mathrm{m} ; \mathrm{C}, \mathrm{D}=50 \mu \mathrm{m} ; \mathrm{E}, \mathrm{F}=10 \mu \mathrm{m}$.

Other host: Arothron meleagris (Tetraodontiformes: Tetraodontidae) deposited at Faculty of Science, University of the Ryukyus (URM-P 34774).

Type 1ocality: Off Mizugama $\left(26^{\circ} 21^{\prime} \mathrm{N}, 127^{\circ} 44^{\prime} \mathrm{E}\right)$, Okinawa-jima Island, Ryukyu Islands, East China Sea, Japan. Collected 22 May 2005 (NSMT-Cr 20929, 20930).

Other locality: Off Akasaki $\left(26^{\circ} 49^{\prime} \mathrm{N}, 128^{\circ} 19^{\prime} \mathrm{E}\right)$, Okinawa-jima Island, Ryukyu Islands, North Pacific Ocean, Japan. Collected 27 November 1995 (RUMF-ZC-01072).

Site of infection: Gill filaments.

Deposition of specimens: Holotype female (NSMTCr 20929); nine paratype females (NSMT-Cr 20930 from A. nigropunctatus); two paratype females (RUMF-ZC01072 from $A$. meleagris).

Etymology: The specific name of the new species, boon$a h$, is a local Japanese name for pufferfishes in Okinawa. The name is used as a noun in apposition.

Remarks. Hatschekia boonah sp. n. possesses a fusiform trunk with posterior lobes and the urosome is remarkably extended, reaching beyond the posterior lobes. The latter character is shared only with $H$. longiabdominalis sp. $\mathrm{n}$., but differs from this species by having the following combination of characters: the lack of four posterior processes and a protruding anterior margin on intercoxal sclerites of legs 1 and 2, cephalothorax without a concave anterior margin, an $\mathrm{M}$-shaped chitinous frame and a greater antenna length/body length ratio $(0.32 \pm 0.01$ vs. $0.19 \pm 0.02$, Table 1$)$.

Specimens of Hatschekia sp., which were not identified by Villalba (1986) from A. meleagris, a host of $H$. boonah sp. n., off Easter Island, Chile, are easily distinguishable from the new species by the cephalothorax with sinuous lateral margin (vs. not sinuous) and not extended urosome is (vs. remarkably extended).

'Kokutenfugu-no-eranomi' is proposed as a new Japanese name of $H$. boonah sp. n.

\section{DISCUSSION}

Hatschekia pholas is redescribed in this paper but some intraspecific variability was found in the setation pattern of legs 1 and 2 when compared with the observations by Pillai (1968). Kabata (1991) suggested that armature on the rami of legs 1 and 2 should be treated with caution because of its high intraspecific variability and the fact that setae are easily lost during collection or handling of specimens. For instance, both H. ostracii and H. khahajya are known to show a wide variability in the setation patterns of the exopods and endopods of legs 1 and 2 (Uyeno and Nagasawa 2009a, 2010b)

In this study, four new species, $H$. longiabdominalis, H. geniculata, H. ellipsocorpa, and H. boonah, also show range and mode in the setation pattern of legs 1 and 2 . Species of Hatschekia usually possess none or one inner seta on the proximal segment of the endopod of leg 2 (e.g. Kabata 1979, 1991, Jones 1985, Pillai 1985, Jones and Cabral 1990, Villalba 1986, Ho and Kim 2001, Uyeno and Nagasawa 2009a, b). So far, no species with more than two inner setae has been described. Therefore, although the inner seta is sometimes inconspicuous, the presence or absence of this seta on the proximal segment of the leg 2 endopod is regarded as an important morphological character and should be accurately described in species diagnoses because it shows no intraspecific variation.

Species of Hatschekia are known to possess three to six caudal setae (e.g. Jones 1985) and the five species dealt with in this paper possess five caudal setae. Although the number of caudal setae in some species is uncertain, the recently described species, such as $H$. $c y$ lindrus Uyeno et Nagasawa, 2009, H. fukurubi Uyeno et Nagasawa, 2010, H. izenaensis Uyeno et Nagasawa, 2010, H. mihkagan Uyeno et Nagasawa, 2010, H. papillifera Kabata, 1991, H. rhodei Kabata, 1991, H. seyi Ho et Kim, 2001, H. siganicola El-Rashidy et Boxshall 2011, H. sumireyakko Uyeno et Nagasawa, 2012 and H. triannuli Uyeno et Nagasawa, 2012, have been reported to have six setae. These observations imply that the number of setae on the caudal ramus is stable in these species and may be used for species identification as a supplementary character.

Pillai (1968) found a few specimens of $H$. pholas that showed a different shape of the cephalothorax with respect to fully grown individuals, but considered them conspecific. All specimens were gravid females with egg sacs (see Pillai 1968, figs. 12 and 14), so we presume that the observed difference in the cephalothorax morphology does not represent intraspecific variability. Hence, we think that two species may be represented in the specimens of $H$. pholas described by Pillai (1968). A detailed 
Table 1. Ratios of body parts of females of Hatschekia pholas, H. longiabdominalis sp. n., H. geniculata sp. n., H. ellipsocorpa sp. n. and $H$. boonah sp. $\mathrm{n}$. The data are shown as the mean \pm standard deviation.

\begin{tabular}{llllll} 
Species & $\begin{array}{l}\text { H. pholas } \\
(\mathrm{n}=10)\end{array}$ & $\begin{array}{l}\text { H. longiabdominalis } \\
(\mathrm{n}=9)\end{array}$ & $\begin{array}{l}\text { H. geniculata } \\
(\mathrm{n}=9)\end{array}$ & $\begin{array}{l}\text { H. ellipsocorpa } \\
(\mathrm{n}=9)\end{array}$ & $\begin{array}{l}\text { H. boonah } \\
(\mathrm{n}=12)\end{array}$ \\
\hline $\mathrm{CeL} / \mathrm{BL}$ & $0.50 \pm 0.06$ & $0.21 \pm 0.02$ & $0.17 \pm 0.01$ & $0.37 \pm 0.05$ & $0.35 \pm 0.01$ \\
$\mathrm{CeW} / \mathrm{BL}$ & $0.54 \pm 0.05$ & $0.34 \pm 0.02$ & $0.23 \pm 0.01$ & $0.58 \pm 0.06$ & $0.46 \pm 0.02$ \\
$\mathrm{TL} / \mathrm{BL}$ & $0.73 \pm 0.03$ & $0.82 \pm 0.01$ & $0.84 \pm 0.01$ & $0.72 \pm 0.07$ & $0.72 \pm 0.02$ \\
$\mathrm{TW} / \mathrm{BL}$ & $0.36 \pm 0.06$ & $0.24 \pm 0.01$ & $0.22 \pm 0.03$ & $0.41 \pm 0.04$ & $0.34 \pm 0.02$ \\
$\mathrm{UL} / \mathrm{BL}$ & $0.10 \pm 0.01$ & $0.10 \pm 0.01$ & $0.05 \pm 0.01$ & $0.05 \pm 0.02$ & $0.07 \pm 0.01$ \\
$\mathrm{UW} / \mathrm{BL}$ & $0.12 \pm 0.01$ & $0.09 \pm 0.01$ & $0.05 \pm 0.00$ & $0.09 \pm 0.01$ & $0.10 \pm 0.01$ \\
$\mathrm{CaL} / \mathrm{BL}$ & $0.07 \pm 0.01$ & $0.04 \pm 0.00$ & $0.02 \pm 0.00$ & $0.04 \pm 0.01$ & $0.03 \pm 0.00$ \\
$\mathrm{CaW} / \mathrm{BL}$ & $0.04 \pm 0.01$ & $0.02 \pm 0.00$ & $0.01 \pm 0.00$ & $0.02 \pm 0.00$ & $0.02 \pm 0.00$ \\
$\mathrm{CeW} / \mathrm{CeL}$ & $1.08 \pm 0.08$ & $1.63 \pm 0.11$ & $1.36 \pm 0.07$ & $1.59 \pm 0.11$ & $1.31 \pm 0.06$ \\
$\mathrm{UW} / \mathrm{HL}$ & $1.25 \pm 0.17$ & $0.94 \pm 0.11$ & $1.16 \pm 0.18$ & $2.08 \pm 0.79$ & $1.54 \pm 0.14$ \\
$\mathrm{~A} 1 \mathrm{~L} / \mathrm{BL}$ & $0.26 \pm 0.02$ & $0.20 \pm 0.01$ & $0.16 \pm 0.00$ & $0.29 \pm 0.02$ & $0.24 \pm 0.01$ \\
$\mathrm{~A} 2 \mathrm{~L} / \mathrm{BL}$ & $0.31 \pm 0.04$ & $0.19 \pm 0.02$ & $0.12 \pm 0.01$ & $0.31 \pm 0.04$ & $0.32 \pm 0.01$ \\
$\mathrm{~A} 2 \mathrm{TL} / \mathrm{A} 2 \mathrm{ML}$ & $0.19 \pm 0.02$ & $0.26 \pm 0.04$ & $0.27 \pm 0.02$ & $0.22 \pm 0.04$ & $0.18 \pm 0.01$ \\
$\mathrm{~L} 1 \mathrm{~L} / \mathrm{BL}$ & $0.14 \pm 0.01$ & $0.11 \pm 0.01$ & $0.09 \pm 0.01$ & $0.15 \pm 0.02$ & $0.12 \pm 0.01$ \\
$\mathrm{~L} 1 \mathrm{ExL} / \mathrm{L} 1 \mathrm{EnL}$ & $1.69 \pm 0.20$ & $1.35 \pm 0.08$ & $1.63 \pm 0.15$ & $1.32 \pm 0.21$ & $1.69 \pm 0.11$ \\
$\mathrm{~L} 2 \mathrm{~L} / \mathrm{BL}$ & $0.16 \pm 0.01$ & $0.12 \pm 0.01$ & $0.10 \pm 0.00$ & $0.17 \pm 0.02$ & $0.14 \pm 0.01$ \\
$\mathrm{~L} 2 \mathrm{ExL} / \mathrm{L} 2 \mathrm{EnL}$ & $1.25 \pm 0.10$ & $0.93 \pm 0.11$ & $1.07 \pm 0.12$ & $1.08 \pm 0.07$ & $1.15 \pm 0.10$ \\
$\mathrm{~A} 1 \mathrm{~L} / \mathrm{A} 2 \mathrm{~L}$ & $0.87 \pm 0.09$ & $1.07 \pm 0.11$ & $1.29 \pm 0.11$ & $0.92 \pm 0.11$ & $0.74 \pm 0.05$ \\
\hline
\end{tabular}

Abbreviations: cephalothorax length (CeL), body length (BL), cephalothorax width (CeW), trunk length (TL), trunk width (TW), urosome length (UL), urosome width (UW), caudal ramus length $(\mathrm{CaL})$, caudal ramus width $(\mathrm{CaW})$, antennule length (A1L), antenna length (A2L), terminal claw length of antenna* (A2TL), middle segment length of antenna (A2ML), leg 1 length (L1L), exopod length of leg 1 (L1ExL), endopod length of leg 1 (L1EnL), leg 2 length (L2L), exopod length of leg 2 (L2ExL), and endopod length of leg 2 (L2EnL).

* This length was expressed as the 'terminal segment length' in Uyeno and Nagasawa (2009a, b).

morphological observation based on numerous specimens and molecular data are needed for this species.

A total of 118 valid species, including the four new species described here, are recognized in the genus Hatschekia. Among these species, 52 (44\%) occur in the North Pacific Ocean and 44 (37\%) are distributed in Japanese waters (see Yamaguti 1963, Jones 1985, Pillai 1985, Castro and Baeza 1986, Villalba 1986, Jones and Cabral 1990, Kabata 1991, Ho and Kim 2001, Uyeno and Nagasawa 2009a, b, 2010a, b, c, 2012; El-Rashidy and Boxshall 2011, Nagasawa and Uyeno 2013, present study). This implies the high biodiversity of Hatschekia around Japan and also points out scarcity of field surveys in other regions of the North Pacific Ocean.

Only five nominal and one unidentified species of Hatschekia are known from six species of tetraodontid fishes but future research may reveal a much higher fauna of Hatschekia on fishes of this family (e.g. Jones, 1985; Villalba 1986; present study).

\section{Key to females of the valid species of Hatschekia parasitic on pufferfishes}

1 The urosome remarkably extended, reaching beyond the posterior lobes on the trunk .............................. 2

- The urosome not remarkably extended ................... 3

2 The intercoxal sclerites of the legs 1 and 2 projected from the middle of the anterior margin bear four blunt processes on the posterior margin
The intercoxal sclerites of the legs 1 and 2 are rod-like without any projections and processes

H. boonah sp. $\mathrm{n}$.

3 The trunk elongate, cephalothom length/body length (CeL/BL) ratio approximately 0.17 ; the abdomen bears a dorsal protrusion; the parabasal papilla well developed, consisting of rod-like process and knoblike process

H. geniculata sp. n.

- The trunk fusiform or ellipsoid, CeL/BL ratio more than 0.30; the abdomen lacks dorsal protrusions; the parabasal papilla does not consist of rod-like structures

4 The endopods of legs 1 and 2 bear one distal seta and one inner seta H. ellipsocorpa sp. $\mathrm{n}$.

- The endopods of legs 1 and 2 bear three and two to three distal setae, respectively, and lack any inner setae H. pholas (Wilson, 1906)

Acknowledgements. We are grateful to Euichi Hirose, Tetsuo Yoshino and Takeshi Sasaki, University of the Ryukyus, for assistance and permission to use their laboratory facilities. We acknowledge Tomohito Sawada and Sunao Yamashiro, Okinawa City, for assistance in collecting samples. Finally, we greatly thank Susumu Ohtsuka, Hiroshima University, for valuable suggestions during the study. Part of this work received financial support from the Ocean Exposition Commemorative Park Management Foundation, Okinawa. 
Boxshall G.A., Halsey S.H. 2004: An Introduction to Copepod Diversity. The Ray Society, London, 966 pp.

Castro R., Baeza H. 1986: Two new species of Hatschekia Poche, 1902 (Copepoda, Hatschekiidae) parasitic on two inshore fishes from Antofagasta, Chile. J. Nat. Hist. 20: 439-444.

El-Rashidy H.H., Boxshall G.A. 2011: Two new species of parasitic copepods (Crustacea) on two immigrant fishes from the Red Sea of family Siganidae. Syst. Parasitol. 79: 175-193.

Froese R., Pauly D. (Eds.) 2012: FishBase. World Wide Web electronic publication, www.fishbase.org, 8/2012.

Hayashi M. 2002: Balistidae. In: T. Nakabo (Ed.), Fishes of Japan with Pictorial Keys to the Species. English Edition. Tokai University Press, Tokyo, pp. 1396-1402.

Ho J.S., Kıм I.H. 2001: New species of Hatschekia Poche, 1902 (Copepoda: Hatschekiidae) parasitic on marine fishes of $\mathrm{Ku}-$ wait. Syst. Parasitol. 49: 73-79.

Humes A.G., Gooding R.U. 1964: A method for studying the external anatomy of copepods. Crustaceana 6: 238-240.

Huys R., Boxshall G.A. 1991: Copepod Evolution. The Ray Society, London, $468 \mathrm{pp}$.

Jones J.B. 1985: A revision of Hatschekia Poche, 1902 (Copepoda: Hatschekiidae), parasitic on marine fishes. N. Z. J. Zool. 12: 213-271.

Jones J.B., Cabral P. 1990: New species of Hatschekia (Copepoda: Siphonostomatoida) from the gills of South Pacific fishes. J. R. Soc. N. Zeal. 20: 221-232.

Kabata Z. 1979: Parasitic Copepoda of British Fishes. The Ray Society, London, $468 \mathrm{pp}$.

Kabata Z. 1991: Copepoda parasitic on Australian fishes, XIII: family Hatschekiidae. J. Nat. Hist. 25: 91-121.

Nagasama K., Uyeno D. 2013: A checklist of copepods of the families Dichelesthiidae, Hatschekiidae and Pseudohatschekiidae (Siphonostomatoida) from fishes in Japanese waters (19162012). Biosphere Sci.: in press.

Nelson J.S. 2006: Fishes of the World. Fourth Edition. John Wiley \& Sons Inc., New York, 601 pp.

Nuñes-Ruivo L.P. 1954: Parasites de poissons de mer ouest-Africains récoltés par M.J. Cadenat. III. Copépodes $\left(2^{\circ}\right.$ note). Genres Prohatschekia n. gen. et Hatschekia Poche. Bull. Inst. Fr. d'Afrique Noire 16A: 479-505.

Pillai N.K. 1967: Copepods parasitic on Indian marine fishes. A review. In: Proceedings of the Symposium on Crustacea. Symposium Series, Mar. Biol. Assoc. India 2: 1556-1680.

Received 16 March 2010

Received in revised form 20 September 2012
Pillai N.K. 1968: Redescription of Caetrodes pholas C. B. Wilson and its transfer to Hatschekia Poche and the description of Hatschekia elliptica n. sp. Crustaceana, Supl. 1: 141-151.

Pillai N.K. 1985: The Fauna of India. Copepod Parasites of Marine Fishes. Zoological Society of India, Calcutta, 900 pp.

Uyeno D., Nagasama K. 2009a: Redescription of four species of Hatschekia (Copepoda: Siphonostomatoida: Hatschekiidae) parasitic on tetraodontiform fishes from Japan. Zootaxa 2110: $1-21$.

Uyeno D., Nagasawa K. 2009b: Three new species of Hatschekia Poche, 1902 (Copepoda: Siphonostomatoida: Hatschekiidae) parasitic on Abalistes filamentosus (Pisces: Tetraodontiformes: Balistidae) from off Okinawa, Japan. Syst. Parasitol. 74: 225 237.

Uyeno D., Nagasawa K. 2010a: Three new species of Hatschekia (Copepoda: Siphonostomatoida: Hatschekiidae) parasitic on boxfishes (Pisces: Tetraodontiformes: Aracanidae and Ostraciidae) from Japan. Syst. Parasitol. 75: 147-158.

Uyeno D., Nagasawa K. 2010b: A new species of parasitic copepod of the genus Hatschekia Poche, 1902 (Siphonostomatoida: Hatschekiidae) from filefishes (Pisces: Tetraodontiformes: Monacanthidae) from off Okinawa, Japan. Syst. Parasitol. 75: $147-158$.

Uyeno D., Nagasawa K. 2010c: The copepod genus Hatschekia Poche, 1902 (Siphonostomatoida: Hatschekiidae) from triggerfishes (Pisces: Tetraodontiformes: Balistidae) from off the Ryukyu Islands, Japan, with descriptions of eleven new species. Zootaxa 2478: 1-40.

Uyeno D., Nagasawa K. 2012: Two new species of the copepod Hatschekia Poche, 1902 (Siphonostomatoida: Hatschekiidae) from angelfishes (Pisces: Perciformes: Pomacanthidae) collected during the KUMEJIMA 2009 Expedition. Zootaxa 3367: $49-59$.

Villalba C. 1986: Contribution al conocimiento del genero Hatschekia Poche, 1902 en Chile (Copepoda: Hatschekiidae). Bol. Soc. Biol. Concepción, Chile. 56: 155-170.

WiLson C.B. 1906: Report on some parasitic Copepoda collected by Professor Herdman, at Ceylon, in 1902. Rep. Gov. Ceylon. Pearl Oyster Fish. Gulf. Manaar 5: 189-210 + Plts. 1-5.

Yamaguti S. 1939: Parasitic copepods from fishes of Japan. Part 5. Caligoida, III. Vol. Jubilare Pro. Prof. Sadao Yoshida 2: 443$487+$ Plts. $14-33$.

Yamaguti S. 1963: Parasitic Copepoda and Branchiura of Fishes. John Wiley \& Sons Inc., New York, 1104 pp.

Accepted 1 October 2012 